ORGANIZATIONAL COLLABORATION IN THE PUBLIC SECTOR: DO CHIEF EXECUTIVES MAKE A DIFFERENCE?

Marc Esteve, PhD candidate at ESADE Business School, Visiting Researcher at Cardiff Business School

Dr. George Boyne, Cardiff Business School

Dr. Vicenta Sierra, ESADE Business School

Dr. Tamyko Ysa, ESADE Business School 


\section{ORGANIZATIONAL COLLABORATION IN THE PUBLIC SECTOR: DO CHIEF EXECUTIVES MAKE A DIFFERENCE?}

Upper echelons theory suggests that the characteristics of chief executives affect the strategic choices of their organizations. In this paper we examine whether the characteristics of top managers make a difference to the extent of inter-organizational collaboration in the public sector. Using survey data from 228 chief executives from Catalonia, we test upper echelons theory, and control for top managers' institutional settings such as the size and the sector of the organization, as well as the socioeconomic context. The empirical results suggest that collaboration is influenced by the characteristics of chief executives: in particular, the extent of collaboration is affected positively by their educational qualifications and concern for self development, and negatively by their age. 


\section{INTRODUCTION}

A major strategic decision that public managers face is whether to develop projects alone or in collaboration with other organizations (O'Leary and Bingham 2009). In order to understand how this dilemma is solved, several authors have paid attention to the determinants of collaboration (Alter and Hage 1993; Bardach 1998; Bryson, Crosby, and Stone 2006; Thomson and Perry 2006; Weiss 1987). In addition, more recently, an effort has been made to provide empirical evidence on the determinants of collaboration in public organizations (Krueathep, Riccucci, and Suwanmala 2010; Lundin 2007; McGuire and Silvia 2010; Mullin and Daley 2010; Smith 2009). These studies have examined explanatory variables such as resource dependency, task complexity, and problem severity.

Conversely, little attention has been paid to the characteristics of public managers and how they affect collaboration; we draw upon upper echelons theory (Hambrick and Mason 1984) to assess the effect of top managers' characteristics on inter-organizational collaboration. Thus, following upper echelons theory, the present paper aims to add to research on the determinants of public collaboration by examining the role of the characteristics of public managers. The question that this article seeks to answer is whether chief executives have an influence on the collaborative activity of their organizations.

Hambrick and Mason (1984) further developed the cognitive view of the firm in the explanation of the strategic decisions and the outcomes of organizations. The cognitive view of the firm was developed by the authors of the Carnegie School who believe in a strong behavioral component of organizations (Cyert and March 1963; March and Simon 1958; Simon 1982), as opposed to the rational neo-economic perspectives that were the mainstreams of organizational theory in the early $20^{\text {th }}$ century. The former 
theorists assume that strategic actions in organizations are strongly influenced by the managerial cognition of their leaders. From this perspective, it is acknowledged that there is too much complexity in the environment of an organization to support the idea of full rationality by senior managers (March and Simon 1958; Simon 1947).

In this vein, the major claim of Hambrick and Mason (1984) is that top managers matter to the development of an organization strategy. Upper Echelons Theory focuses on the person who is at the top of the organization, and argues that the characteristics of top managers will affect how they interpret the external environment. In a nutshell, Hambrick and Mason (1984) posit that senior managers do not evaluate objectively their entire environment before taking a strategic decision, due to its complexity. Rather, they look at the environment through a lens formed by their personal experiences, values, and personalities. These are reflected in observable managerial characteristics such as the manager's age, tenure in the organization, level of education, and gender. Each of these characteristics can affect how the top manager interprets constraints and opportunities, and can therefore be used to predict an organization's strategy (Ansell and Gash 2008; Hambrick and Mason 1984).

The responsibility that public sector managers have in pursuing collaborative strategies has been discussed in the public networks literature (O'Leary and Bingham 2009; Williams 2002). However, as Rethemeyer (2005) notes, this literature has not established definitive conclusions about the influence that public managers have on the formation of collaborations. Some argue that collaborations do not occur as a result of the choices of managers, but rather because they face highly complex projects that cannot be developed alone. Thus, public managers do not have a critical effect in decisions regarding collaborations since these are 'unavoidable', meaning that the only possibility for the project to be developed is via collaboration (see, for example, 
Kickert, Klijn, and Koppenjan 1997). By contrast, Agranoff and McGuire (2003) reassess the role of public managers in inter-organizational collaboration, and consider them as crucial actors in their creation. According to this view, public managers have the discretion to decide if they want to achieve their organization's objectives via collaboration.

The remainder of this paper is organized as follows. In the next section, we describe the work that has been done in the area of public administration regarding the determinants of collaboration. Next we set out hypotheses on how the characteristics of public managers affect the collaborative activity of their organizations. The data and methods used in this study are then explained. Subsequently, we present the results of this study, consider the theoretical implications and propose an agenda for future research.

\section{PRIOR RESEARCH ON THE DETERMINANTS OF INTER- ORGANIZATIONAL COLLABORATION}

Over recent years there has been increasing research on the determinants of interorganizational collaboration in the public sector (McGuire 2006; McGuire and Silvia 2010; Mullin and Daley 2010). In the present study, we draw upon O'Leary and Bingham $(2009,3)$ who define collaboration as a "concept that describes the process of facilitating and operating in multiorganizational arrangements to solve problems that cannot be solved or easily solved by single organizations. Collaboration means to colabor, to achieve common goals, often working across boundaries and in multi-sector and multi-actor relationships." The decision to develop a project in collaboration is highly complex and is the result of several factors (Krueathep, Riccucci, and Suwanmala 2010). These factors can be classified into three categories: the environment 
that surrounds the organization, its internal characteristics, and the characteristics of the chief executive. We now proceed to review the theoretical and empirical work on collaboration that has investigated these three types of explanatory variables.

\section{Environmental Factors}

A large body of literature suggests that organizational environments affect substantially the creation and development of collaboration (Hodge and Greve 2007; Koppenjan and Enserink 2009; Mandell and Steelman 2003; O'Toole 1997; Weiss 1987). An important part of the organization's environment is population density. Empirical studies suggest that organizations operating in municipalities with low density will collaborate more (McGuire and Silvia 2010). This can be attributed to the fact that the actors know each other and they are already familiarized with most of their possible partners who are likely to be geographically close to them. Furthermore, Krueathep, Riccucci, and Suwanmala (2010) argue that municipalities formed by citizens that share, to a large degree, the same occupation will collaborate more. For instance, if a municipality is mainly dedicated to agricultural activities one would expect that its organizations end up by working together in some projects, since their activities are in the same field.

Arguably, public organizations are more likely to develop collaborations that take advantage of the capabilities of other organizations when they have to tackle complex problems (O'Toole 1997; Silvia and McGuire 2010; Weiss 1987). For example, in their study of local emergency management in the U.S., McGuire and Silvia (2009a) explain how those managers facing severe problems were significantly more likely to solve them via collaboration. In addition, other studies report that those areas responsible for economic development, or environmental management, tend to collaborate more than areas such as education and cultural promotion, since managers 
perceive them as more complex (Agranoff and McGuire 2003; Krueathep, Riccucci, and Suwanmala 2010). Hence, public managers may rely on joint work with other organizations to ensure the development of critical projects (Steijn, Klijn, and Edelenbos 2011).

In a number of cases, empirical evidence has shown that public organizations that have to respond to several stakeholders, whose values and interests are in conflict, will collaborate more (Krueathep, Riccucci, and Suwanmala 2010; Lundin 2007). These authors state that such situations occur because public managers tend to use collaborations as a resource to accommodate, or at least to consider, the different demands of all the stakeholder groups. Thus, the more different are the demands of its stakeholders, the more the public organization will collaborate.

Lastly, McGuire and Silvia (2010) observe that the distance between municipalities and their state capital is negatively correlated with collaboration, because state capitals host a significant proportion of the governmental bodies. The further the organization is from these possible partners, the less likely it will be to collaborate with them.

\section{Organizational Factors}

It has been argued that there are several organizational variables that influence collaboration (Blanc-Brude, Goldsmith, and Valila 2007; Bryson, Crosby, and Stone 2006; Krueathep, Riccucci, and Suwanmala 2010; Lundin 2007; McGuire 2009; McGuire and Silvia 2010; Mullin and Daley 2010; Smith 2009). For instance, public organizations that are formed as quasi-autonomous executive agencies have been identified as more collaborative than those that are embedded in government departments, whether at the local, regional or national level (McGuire and Silvia 2010; 
Smith, 2009). This can be explained since collaborations need priori investments, both in terms of time and energy costs (Agranoff 2006); arguably, those public managers in executive agencies have more freedom to decide where to invest their resources, and as a result they are more able to devote their resources to the development of collaborations (McGuire and Silvia 2010). Moreover, this independence can be accompanied by fewer resources within the organization, when compared to central government bodies, and this will also favor the development of collaborations (Smith 2009).

It is well established in the management literature that having standardized procedures can reduce the uncertainty of some managerial activities (Galbraith 1974; Mitchell and Nault 2007; Thomson 1967). Consequently, managers that can rely on written documents to clarify the steps that they have to take to form collaborations will be able to avoid some of the uncertainty associated with this strategy. For instance, Krueathep, Riccucci, and Suwanmala (2010) find that organizations that have standard procedures to follow when they have to develop inter-organizational projects tend to collaborate to a greater extent. These standard collaboration procedures can be aimed to facilitate activities such as decision making with other partners, or the distribution of responsibilities among all the actors involved in the collaboration.

Bryson, Crosby, and Stone (2006) propose that a major determinant of collaboration is the past experience of the public organization. More specifically, they suggest that having previous successful experience with collaboration will enhance the level of current collaboration. In the same vein, Ansell and Gash (2008) propose that those organizations that have had bad experiences with past collaborations will be more reluctant to engage again in inter-organizational projects. Therefore, the success of the 
history of collaboration by a specific organization has to be considered when analyzing its likelihood of engaging in current collaborations.

Finally, organizational size has been also identified as a determinant of interorganizational collaboration (Krueathep, Riccucci, and Suwanmala 2010). Arguably, big organizations have higher resources because they benefit from economies of scale, and can afford the risks and costs that collaborations entail (Graddy and Chen 2006).

\section{Top Manager Characteristics}

Environmental and organizational variables have dominated empirical work on explaining collaboration. However, there is another trend that is starting to emerge in collaboration research. This recognizes the importance of managers in decisions on inter-organizational collaborations (see McGuire and Silvia 2010). The fundamental characteristic of this perspective is that the focus of analysis is not the organization solely but also its managers.

For instance, McGuire and Silvia (2010) include some characteristics of public managers in a model to explain why local emergency organizations engage in collaborative activities with other public organizations. By surveying 344 U.S. local emergency directors, they find support for a relationship between public managers' education levels and their collaboration with other public organizations. In addition, those emergency managers who had attended training courses in emergency management collaborate to a greater extent than those who did not.

In a very different setting, Krueathep, Riccucci, and Suwanmala's (2010) study of the determinants of collaboration in Thailand local governments emphasizes the importance of environmental and organizational factors to collaboration. However, they also consider the impact of some attitudes of the politician who is responsible for the 
organization. In their findings, the authors suggest the politicians' attitudes regarding the expansion of government affects collaboration. Politicians who have a conservative attitude towards the role of public organizations will develop more inter-organizational collaborations. The explanation is that collaborations allow them to develop more projects without having to enlarge the government by hiring more public servants, or creating more departments within the government. Although this study was on politicians rather than managers the evidence is consistent with the view that individuals at the top of an organization can make a difference to the extent of collaboration.

\section{Summary and Implications}

The literature on collaboration presents substantial evidence that environmental and organizational variables affect collaboration by public organizations. Nevertheless, the evidence is limited in a number of important respects.

First, some of these studies focus on a specific field of activity, such as open space protection or emergency management, rather than exploring the multiple fields where public organizations operate. A second problem is that most studies only consider collaboration within the public sector, or even only with specific public organizations. Collaboration can occur with several types of organizations, whether these are public, private or non-profit. Collaboration can be understood as vertical, for example if occurs between a federal government and a municipality; or can be horizontal, for example if two municipalities decide to develop a project together (Smith 2009). The literature on public collaboration has rarely considered the whole portfolio of collaborations of public organizations up, down and across the public sector, and between public organizations and private and non-profit organizations. 
The most notable deficiency in studies of the determinants of collaboration, however, is the neglect of the characteristics of public managers. Recent work on collaboration determinants has added some features of public leaders to the models explaining why public organizations collaborate (Krueathep, Riccucci, and Suwanmala 2010; McGuire and Silvia 2009a, 2010). Although these studies have added a few variables reflecting public managers' characteristics to their models, they have not been derived from a comprehensive model of the characteristics of chief executives that are likely to influence organizational strategy. This is because they were mainly focused on environmental and organizational variables. Therefore, they provide a limited assessment of the effect that public managers have on collaboration.

In order to remedy these deficiencies, in this article we consider collaboration in its broadest sense, by analyzing vertical and horizontal collaborations with several types of organizations. Also our sample is not limited to a specific field of activity rather we consider numerous fields of the public domain. We also extend previous research on the determinants of inter-organizational collaboration by applying upper echelons theory to understand the effect of chief executives on collaboration. In doing so we follow McGuire and Silvia $(2009 \mathrm{~b}, 1)$ in their call for "examining the actions and behaviors of network participants". We take the public managers' characteristics as our explanatory variables, while controlling for organizational and environmental constraints. This will allow us to examine whether the characteristics of public managers affect the extent of inter-organizational collaborations. 


\section{TOWARDS A MODEL OF THE COLLABORATIVE PUBLIC}

\section{MANAGER}

We apply upper echelons theory (Hambrick and Mason 1984) to identify the characteristics of managers that may influence collaborative activities with other organizations. Drawing from the cognitive view of the firm, Hambrick and Mason argue that top managers make a difference to organizational strategy. This theory argues that the characteristics of the most senior manager will affect how he/she interprets the environment of the organization. Hambrick $(2007,334)$ identifies two major elements of upper echelons theory: 1) "executives act on the basis of their personalized interpretations of the strategic situations they face, and 2) these personalized construals are a function of the executives' experiences, values and personalities". Thus, managers' characteristics are likely to have a significant bearing on the organization's strategy. Many empirical studies from the management literature have tested upper echelons theory to relate senior managers' personal characteristics to a large subset of strategic decisions (see, among others, Carpenter, Sanders, and Gregersen 2001; Chatterjee and Hambrick 2007; Nadkarni and Herrmann 2010). For example, Eisenhardt and Schoonhoven (1996) report that factors such as the top managers' skills have an influence on strategic alliances.

What, then, are the specific characteristics of chief executives that can be expected to influence whether they lead their organizations towards more or less collaboration? In order to answer this question, we consider the major concepts proposed by upper echelons theory (Hambrick and Mason 1984), and develop arguments on their potential relevance to collaboration by public organizations. 


\section{Manager's Age}

Hambrick and Mason (1984) note that, for several decades, research has found that managerial age is related empirically to a large subset of organizational characteristics, and that the age of the top manager influences his/her strategic decisions. For example, young managers are more likely to expand their organizations by developing projects with other organizations, when compared to older counterparts (Child 1974; Hart and Mellors 1993). One possible explanation is provided by Barker and Mueller (2002) who report that younger managers are more likely to take risky decisions, such as an interorganizational collaboration. Another explanation is provided by the physical consequences of age for cognition. It has been noted that cognitive abilities diminish with age, and as a result managers are less able to learn, remember and reason (Bantel and Jackson 1989), making them less capable of implementing new ideas or developing new behaviors (Chown 1960). Finally, a third plausible explanation is that younger managers are more concerned with their career progression, whereas older managers seek job stability (Carlsson and Karlsson 1970; Hambrick and Mason 1984). It has long been observed that as managers get older they become more worried about their financial and career security (Carlsson and Karlsson 1970). This may be translated into older managers being less willing to engage in collaborations. Therefore, we hypothesize:

Hypothesis 1: The top manager's age is negatively related to inter-organizational collaboration.

\section{Manager's Tenure}

Grimm and Smith (1991) observe that organizations with long tenured managers are less likely to develop new strategic actions; and, moreover, they are also less likely to 
contract out for the delivery of public services (Brudney et al. 2005). Public managers with shorter tenures may be more willing to collaborate to show that they are developing more activities as compared to those managers who have been in their positions for many years. Furthermore, Miller (1991) explains that most long tenured managers tend to become 'stale in the saddle', and ignore changes in their organizational environments since they become accustomed to the same type of activities. One of the reasons may be that long tenured managers are less motivated towards organizational changes and prefer to focus their efforts towards the daily routine of their organizations (Hambrick and Fukutomi 1991). These arguments suggest that long tenured managers will be more reluctant to collaborate, because this will imply developing projects in a different setting that may not be familiar to them. Thus, we hypothesize:

Hypothesis 2: The top manager's length of tenure is negatively related to interorganizational collaboration.

\section{Manager's Formal Education}

Education indicates to a large degree the knowledge and skill base of managers, and so is likely to influence strategic decisions (Bantel and Jackson 1989; Hambrick and Mason 1984). As an example, Bantel and Jackson (1989) develop this argument by linking the level of education of top managers of banks with their strategies, arguing that managers who are more highly educated will be more aware of the latest developments in the field of activity of their organizations. Similarly, McGuire (2009) finds positive correlations between the levels of formal education of emergency managers and collaboration (managers with graduate degrees reported higher levels of collaborative activities). Arguably, those managers with better education have more 
skills that provide them with confidence in their capacity to manage collaborations with other organizations. Therefore, we hypothesize:

Hypothesis 3: The amount of formal education of the top manager is positively related with the development of inter-organizational collaborations.

\section{Manager's Functional Track}

Hambrick and Mason (1984) argue that top managers tend to have a generalist perspective when managing their organizations, but they cannot avoid the effects of their field of training. Functional track is understood as the major area of study that the manager has pursued. For instance, it is suggested that managers who have studied degrees in health may have a different approach to organizational strategy than those who have studied economics. This is because in many non-business degrees the education programs offered by universities do not consider how to manage an organization. Instead, they are focused on the substance of each academic field. Therefore, Hambrick and Mason (1984) suggest that the manager's functional track must be considered as another important influence on the strategic decisions of organizations. Following this perspective, several studies have empirically corroborated the relation between the functional track of senior managers and their strategic decisions (Bamber, Jiang, and Wang 2010; Chaganti and Sambharya 1987; Jensen and Zajac 2004).

When analyzing the determinants of strategic mergers in public health organizations, Noordegraaf, Meurs and Montijn-Stoopendaal (2005) found that managers with management education were more likely to develop mergers. A plausible explanation is that their education enables them to understand better the situation of their organizations and the possible benefits of collaborations. In addition, they may be 
less concerned by the uncertainty and the risks associated with collaborations, as they have knowledge and skills in how to manage these risks and uncertainties due to their management education. Therefore, we differentiate between those managers who have been trained in degrees that are business related (degrees in management, economics, and masters in business or public administration) and those who have been trained in non-business related subjects (e.g., medicine, biology, psychology, philosophy, history), and we hypothesize:

Hypothesis 4: Managers with business-related degrees are more likely to engage in inter-organizational collaborations.

\section{Manager's Self-Development}

The management literature suggests that the strategic activities of organizations will be affected by the degree of organizational training that managers have received (Bantel and Jackson 1989; Hambrick and Mason 1984). Moreover, the in-company courses that public managers have undertaken have been found to have a positive effect on how much they collaborate (McGuire 2009; McGuire and Silvia 2010). These studies report that managers attending more emergency management courses collaborate to a greater extent. A possible explanation is that, during these organizational courses, public managers meet other executives who can become potential partners in future collaborations. Indeed, as Bardach (1998) argues, collaboration rarely occurs between strangers. Therefore, managers attending the courses seem more likely to develop collaborations. Even when the courses do not have an explicit focus on collaboration, the skills that managers develop in these courses can help their daily duties, which, as Rainey (2003) states, include negotiating with their environment. Other research points to the importance of managerial pro-activity in the success of collaborations (Goerdel 
2006). Therefore, the number of courses that each manager undertook in their organizations may not only reflect the specific knowledge that they obtain, but also serve as a proxy for their proactive personality. Thus, managers showing more selfdevelopment attitudes by attending in-company training courses may be more successful in negotiations with their environment, and this will give them confidence to develop inter-organizational collaborations. These arguments lead us to propose:

Hypothesis 5: The degree of the top manager's self-development is positively related to inter-organizational collaboration.

\section{Manager's Gender}

Males and females differ in how they manage public organizations (Fox and Schuhmann 1999; Jacobson, Palus, and Bowling 2010; Meier, O'Toole, and Goerdel 2006). When comparing male and female managers' decision-making, it seems that females are more willing to involve stakeholders in the process (Fox and Schuhmann 1999). Meier, O’Toole and Goerdel (2006) argue that females manage organizations in a more flexible and participatory way, whereas male managerial styles tend to be more hierarchical and rigid. Therefore, it is conceivable that a public manager's gender may play an important role in inter-organizational collaboration. Prior research has not addressed, to our knowledge, how the gender of the top manager affects interorganizational collaborations. One study comes close by assessing the relationship between public managers' gender and their networking activities with other actors (Jacobson, Palus, and Bowling 2010). The authors found differences in the networking contacts of males and females, and that male managers tend to interact slightly more with some actors than their female counterparts. However, this study did not focus on collaboration, but on the personal networking contacts of the managers. Regarding 
collaboration, evidence from the management literature suggests that female managers tend to adopt a collaborative approach when leading an organization (Aldrich 1989; Buttner 2001; Sorenson, Folker, and Brigham 2008). Female managers have been identified with a managerial style that places more importance on the development of inclusive relations with stakeholders, and is more likely to define the organization's strategy based on concepts such as collaboration, cooperation and participation (Wajcman 1998). Thus, we present the following hypothesis:

Hypothesis 6: Public organizations led by female managers are more likely to engage in inter-organizational collaborations than those managed by male managers.

\section{METHODS}

\section{Data Sources}

In order to test the above hypotheses, we use Web survey data from 228 chief executives in Catalonia. The organizations that were included in our study are executive agencies created by the local or regional governments. Executive agencies are public organizations formed apart from the government bodies to fulfill specific objectives, and provided with their own staff and resources (James 2003). These organizations are accountable to and funded by a specific government body. In the case of Catalonia, these agencies can be created not only by the Catalan national government but also by local governments (Martínez-Alonso and Ysa 2003). Due to the lack of non-politically appointed managers in central Catalan government bodies, the strategic decisions developed in these organizations are rarely the result of an individual decision by a manager. Instead, they are taken by a political team (Longo 2008). By contrast, in executive agencies there is an identifiable top manager who holds the responsibilities 
for the strategic decisions of the organization. Thus, the Catalan executive agencies represent a useful context for testing how top public managers influence collaboration. This was corroborated by informal interviews with public managers from different types of public Catalan organizations, prior to the sampling process. Since all executive agencies of Catalonia were included in the sample, it contains a large subset of services ranging from health to economic development projects. Table 1 shows the frequencies for each field of activity included in the sample.

Insert Table 1 about Here

The objective of the Web survey was to gather data from the top manager of each public organization. Only one respondent was used for each organization, because the chief executive is most likely to know about the extent of collaboration across all organizational activities.

Before sending the Web survey, we checked the content validity of the survey constructs by conducting eight interviews. Three of the interviewees were academics with a deep knowledge of Catalan public administration, from the management and law domains; the other five interviewees - with titles including General Director, Director of the Health Public Enterprises or Area Manager- were senior managers from different parts of the public sector, such as the national government of Catalonia or a local government, and from different fields, including health and economic development. The respondents were chosen according to their knowledge and experience in the different areas of the Catalan public sector. During the interviews, conducted by one or two of the paper authors, we covered a series of open-ended questions and we also asked them to complete the Web survey to discuss any possible misunderstanding. These 
interviews, which had an average duration of one hour, led to refinement of the construct definitions and the questionnaire items for the Web survey.

Subsequently, we conducted a pre-test with a randomly chosen sample of our database $(n=50)$ to assess factors such as clarity of wording, the ease of completing the survey, and estimated completion time. This pre-test allowed us to alter some of the questions, either by modifying the question formulation, or by deleting redundant questions, or by including new questions to better reflect specific concepts.

After the first two stages, the Web survey was sent to the complete sample in September of 2010, and a reminder was sent within three weeks. Overall, 380 responses were received, achieving a response rate of $30 \%$. Even though this is a low response rate, it is still higher than those obtained in previous studies on collaboration determinants (Krueathep, Riccucci et al. 2010; McGuire and Silvia 2010). As Hambrick, Geletkanycz et al. (1993) note, studies using upper echelons theory have often worked with response rates of $10-12$ percent; this is because the focus of these studies is on personal characteristics of chief executives, and they are not particularly eager to providing their personal details.

Since it was essential to ensure that the respondents were the chief executives of their organizations, several questions were aimed at confirming their status. Those cases where the respondents reported that there was someone in the organization with a higher level of managerial responsibility were withdrawn from the sample (representing 81 cases). Also we dropped from the sample those cases where respondents were politicians instead of managers (representing 49 cases). 20 cases were also withdrawn from the final sample due to lack of information on the dependent variable, or on the questions aimed at distinguishing the managerial responsibility of the respondent. In addition, two cases were omitted since they came from private organizations. Finally, 
data for the socioeconomic context of each organization was gathered from the Catalan Institute of Statistics (Idescat) from the 2010 census.

Since the present study is developed by using perceptual measures for the dependent and some of the explanatory variables from the same respondent, Common Method Bias (CMV) may occur (Podsakoff and Organ 1986). To reduce the likelihood that respondents "edit their responses to be more socially desirable, lenient, acquiescent, and consistent with how they think the researcher wants them to respond"' (Podsakoff et al. 2003, 888), respondent anonymity was guaranteed, and this was emphasized in several parts of the survey. In addition, as these authors recommend, we segmented the questions pertaining to the predictor and criterion variables into different sections of the survey. Thus, CMV seems unlikely to be a significant problem in the context of this research.

\section{Measurements}

\section{Inter-Organizational Collaboration}

The concept of collaboration has had many interpretations in the public management literature (see, for a discussion, McGuire and Silvia 2010). In order to operationalize this concept, we follow the argument by Koontz and Thomas (2006) collaboration should be measured by actual activities, rather than just agreements between two or more organizations. Thus, we have built on a previous measure of collaboration activities used in several studies (McGuire and Silvia 2009a, 2010; Silvia and McGuire 2010). However, since these studies focused on emergency management, we have modified the measure by extending it beyond activities that are exclusively related to that context. In the informal interviews with chief executives we asked them to identify the main activities that they undertake in collaboration. Finally, the following eleven 
main collaborative activities were identified: (1) Informal Cooperation; (2) Mutual Aid Agreements; (3) Provide Training; (4) Receive Training; (5) Joint Planning; (6) Provide Equipment; (7) Receive Equipment; (8) Provide Technical Assistance; (9) Receive Technical Assistance; (10) Provide Grant Management; and (11) Receive Grant Management. Each of the activities is assessed on a scale with six points according to the number of projects that the organization develops in collaboration with other organizations (from 0 collaborative projects to more than 50). Thus, in each of the eleven collaborative activities the respondent assessed how many projects where being developed with other organizations (public national organizations, public regional organizations, public local organizations, private organizations and non-profit organizations). Those who report that they did not develop any project for a specific collaborative activity where assessed with a value of zero for that collaborative activity (out of the eleven collaborative activities); whereas on the other extreme, those developing more than 50 collaborative projects on that collaborative activity received a value of five. The dependent variable is an additive measure of these eleven activities that public managers may develop in collaboration with other organizations. Thus, the dependent variable is formulated as follows:

$$
Y_{i}=\sum_{j=i}^{11} C_{j}
$$

where for every organization (i), $Y_{i}$ is the additive measure of collaboration, and $C_{j}$ is a value that ranges from 1 (developing 0 collaborative projects) to 5 (developing more than 50 collaborative projects) for each of the eleven different types of collaborative activities (j) which ranges from 1 to 11 . The values of $Y_{i}$ vary from 0 to 55 ; those organizations with a zero value do not develop any activity in collaboration, whereas those with a value of 55 develop more than 50 projects in collaboration with other 
organizations for each of the 11 collaborative activities listed. Finally, the Cronbach's Alpha of the variable is .92 .

We are aware of the complexity that measuring a concept such as collaboration entails; of course some organizations can engage in collaborations that go beyond the activities that we have listed. However, the measure does cover the tendency of each organization to collaborate. Table 2 presents the frequencies for each collaborative activity.

Insert Table 2 about Here

\section{Manager's Characteristics}

The explanatory variables we consider are the top manager's age, job tenure, formal education, functional track (area of specialization), participation in organizational training courses and gender. Age was measured by asking them about their date of birth, to calculate the actual age of each manager. Tenure was measured by the number of years the manager has served in his/her current position. Formal Education was assessed by a 7 -point scale $(1=$ Elementary School; $2=$ School; $3=$ Professional Education; $4=$ High School; $5=$ Bachelor; $6=$ Master; $7=\mathrm{PhD})^{1}$. This was recoded into four categories $(1=$ Non University Degrees; $2=$ Bachelor; $3=$ Master; $4=\mathrm{PhD})$ because of the small number of cases in the first three points on the scale. The manager's Functional Track was measured by asking respondents about the field of their main formal education. The researchers then created a dichotomous variable $(0=$ Non-Business Related, $1=$ Business Related) with those qualifications that were business related (such as business administration, or economics), and those that were

\footnotetext{
${ }^{1}$ Note that in Catalonia those students who want to enroll in university studies must undertake a two year course that is known as High School (from 16 years to 18 years old). Thus we refer to 'School' as the period immediately after Elementary School. In addition, students can undertake a two year course that is aimed at training them for specific jobs, such as plumber or sports instructor, among others. We refer to this as Professional Education.
} 
not (such as medicine, philosophy, or architecture). The degree of Self-Development Attitude was assessed by measuring the in-company courses that managers had taken since they started to work at the organization using a 5-point scale that ranges from 1 (Very Low) to 5 (Very High). It should be noted that we did not measure the courses that the organization offers, but the courses that the manager had actually taken. Therefore, this measure is a proxy for the orientation towards self development by each manager. Finally, Gender was coded as $0=$ Female and $1=$ Male.

\section{Control Variables}

Following recent work on inter-organizational collaboration determinants (Bryson, Crosby, and Stone 2006; Krueathep, Riccucci, and Suwanmala 2010; McGuire and Silvia 2010; Mullin and Daley 2010), several control variables were included in the analysis. These variables measure the organizational and socioeconomic context of collaboration. The first control variable is Size, measured as a 7 -point scale $(1=0-5 ; 2=$ $6-20 ; 3=21-50 ; 4=51-100 ; 5=101-500 ; 6=501-1000 ; 7=$ more than 1000$)$ to assess the number of workers in the organization. Secondly, we measured Environmental Complexity to assess the divergence of the interests of the organization's stakeholders by asking the managers about the degree to which their stakeholders' interests differ (ranging from $1=$ Not Differing at All, to $5=$ Extremely Differing). This is because the more complex is the organization's environment, the more the organization is likely to collaborate (Krueathep, Riccucci, and Suwanmala 2010). In addition, following these authors, we included a dichotomous variable to assess whether the organization had Standard Procedures to develop collaborations $(0=$ No, $1=$ Yes $)$, since it has been argued that they are positively related to collaboration (Krueathep, Riccucci, and Suwanmala 2010). We also controlled for the manager's perception of success of 
previous collaborative activities by using a 5-point scale (ranging from $1=$ Not Successful at All, to $5=$ Extremely Successful). Lastly, in line with previous studies of collaboration determinants (Krueathep, Riccucci, and Suwanmala 2010; McGuire and Silvia 2010; Mullin and Daley 2010) other control variables reflect the socioeconomic context of the public organization: Population Density of the municipality, if the municipality mainly had an Agricultural Economy (total number of workers of the municipality / workers of the municipality that work on the agriculture industry), and two dummy variables to control for whether the municipality contained the Province Capital and was a Rural Area $(0=$ No, $1=$ Yes $)$. Table 3 displays the main descriptive statistics and correlation matrix with related p-values for the significance tests of the quantitative variables.

Insert Table 3 about Here

Overall it can be observed that the correlations between the explanatory variables are low or moderate (see table 3). Multicollinearity was assessed formally using variance inflation factors (VIF) and the coefficients were all below 5, indicating that multicollinearity should not be a problem for the interpretation of the regression results (Damanpour and Schneider 2009; Hair et al. 2006).

\section{RESULTS AND DISCUSSION}

Since our dependent variable -collaboration- is normally distributed (KolmogorovSmirnov test showed normality at $\mathrm{p}<.001$ ), we conducted ordinary least squares regression analysis to evaluate the hypotheses. As shown in Table 4, three different models are tested. The first one includes only variables measuring the characteristics of 
the environment in which each organization operates. Model 2 also includes the organization's characteristics, and Model 3 adds the managerial variables.

Overall, the environmental characteristics explain little variation in collaboration $\left(\mathrm{R}^{2}=11.1 \%\right)$, but when the organizational characteristics are included, the $\mathrm{R}^{2}$ rises to 31.6\%. This improvement is statistically significant at $p<.001$. Finally, when the top managers' characteristics are taken into account, the model explains more than the $47 \%$ of the variation in collaboration. This improvement is also significant at $p<.001$. This lends support to the underlying thesis of this paper that the characteristics of public managers need to be taken into consideration in order to understand why public organizations engage in collaborative activities.

Table 4 shows that the manager's age has a significant negative effect on collaboration. The relation indicates that an increment of one year in the manager's age will be related with a decline of 0.519 points in the dependent variable collaboration. This supports our first hypothesis that young managers will collaborate more than older managers. Thus, whether this is because young managers are more concerned with their career progression (Hambrick and Mason 1984; Stevens, Beyer, and Tryce 1978), or because they are less reluctant to take risky decisions (Barker and Mueller 2002), those organizations led by young managers collaborate more than those headed by older managers. Hypothesis 2, that managers with short tenures will collaborate more, was not supported. This finding is consistent with Krueathep, Riccucci, and Suwanmala (2010) who also report no relation between the manager's tenure and the extent of collaboration of their organizations. Managers who are newly appointed may have strong motives to collaborate, since they are keen to show results; however, they may not have well-developed leadership skills, and lack contacts with potential partners (Krueathep, Riccucci, and Suwanmala 2010). In addition, chief executives with longer 
tenure might feel more secure in their organizational status, making them less averse to take organizational risks such as those that entail the development of collaborations. If so, these effects of short tenure may cancel out, and explain why we do not observe any direct relation between the top manager's tenure and collaboration.

The results show that the top manager's educational qualifications are a significant predictor of collaboration, as expected. In the same vein as McGuire (2009), we found that the higher the final degree of the manager, the more the organization collaborates. We further analyzed these results by including a set of dummy variables in the model for each of the four categories of education (no-degree, bachelor degree, master degree, and $\mathrm{PhD}$ degree). The results showed that the effect of education on collaboration is largely derived from the highest level of educational achievement: if the $\mathrm{CEO}$ has a $\mathrm{PhD}$ then the level of collaboration is higher. Different levels of education below PhD level are less important for the extent of collaboration. As Agranoff (2006) explains, managing collaborations is no easy job and requires specific managerial skills such as bargaining, negotiation and leadership. In this sense, our results suggest that those managers who have acquired better skills due to their higher educational levels will be less reluctant to confront the managerial complexities that collaborations entail.

However, the field in which managers studied their university degrees does not seem to influence collaboration, differing from previous evidence (Noordegraaf, Meurs, and Montijn-Stoopendaal 2005). Our results do not show differences between managers with a business-related functional track and managers that did non-business related studies. This may be because education degrees in business-related fields (for example, MBA) emphasize the importance of competition rather than collaboration (Giacalone and Thompson 2006), and this counteracts any effect of generic management education. 
The coefficient for the self-development attitude of public managers provides clear support for Hypothesis 5. Managers that get out of their offices and participate in organizational courses tend to collaborate more. An increase of one point in the self development scale is related with a rise of 2.120 in the variable collaboration. As suggested by McGuire and Silvia (2010), chief executives attending these courses can interact with other participants and make contacts with potential partners. The causal order between self development and collaboration is difficult to determine, since it could be the case that some managers engage in more courses when they face the difficulties that collaborations entail. Nevertheless, our results are supported by previous research pointing to a significant link between the number of interactions that top managers have with other managers and collaboration (Goerdel 2006).

The results suggest that there are no significant differences regarding gender. Thus, Hypothesis 6 is not supported. Although the literature describes female managers as being more collaborative and cooperative when managing their organizations (Aldrich 1989; Brush 1992; Buttner 2001; Sorenson, Folker, and Brigham 2008), our results show that male and female public managers have much the same effect on interorganizational collaboration. Hence, it seems that although female managers may be more collaborative in their managerial styles (Guy and Newman 2004), this does not affect the extent of collaboration of the organizations that they manage.

The insignificance of some variables such as the manager's tenure, functional track or gender might be due to having too few observations to estimate regression coefficients with accuracy. Therefore future studies should still consider their effect on strategic decisions.

The statistical evidence does not provide support for the argument that collaborations are influenced by the organization's environment. Actually, as table 4 
shows, none of the five coefficients are statistically significant. Having a high population density, operating in the provincial capital, in a rural based area or in a municipality that it is based on an agricultural economy, or operating in complex environments does not seem to affect the extent of collaboration. The different effects of environmental variables on collaboration that we have found in comparison with previous literature on collaboration determinants may be explained by the fact that we considered collaboration with public, private and non-profit organizations, and in several sectors. This differs from most of the studies that report effects of environmental factors since they were focusing on inter-governmental collaboration, and also in some cases their analysis was narrowed to one sector of activity (McGuire 2009; McGuire and Silvia 2009a, 2010; Mullin and Daley 2010). For instance, in contrast to Krueathep, Riccucci, and Suwanmala (2010), we did not find an effect of environmental complexity, so having stakeholders with highly divergent demands does not affect collaboration. This may be because Krueathep et al's sample was city mayors rather than public managers. Mayors may be more sensitive to the opinion of different stakeholders and, therefore, use collaboration to try to avoid conflict between different stakeholder demands that can have a negative effect on their re-election. This may be why environmental complexity affects collaboration by organizations managed by politicians but not by those managed by chief executives. In addition, population density did not have a a significant effect on collaboration. It has been argued that low population density may increase collaboration because it enables diferent actors to better know each other; however, it can be the case that in environments with high population densities the number of possible partners would be higher. This could counteract the effect of familiarity that exist between organizations operating in environments with low density populations. 
Control variables referring to the effect of organizational characteristics do have a strong effect on collaboration. As Krueathep, Riccucci, and Suwanmala (2010) find, there is a positive relation between having standard organizational procedures to collaborate and the degree of organizational collaboration. In addition, our results show that the size of the organization also makes a difference to collaboration: organizations with more employees engage in more collaborative activities. As the literature on collaboration suggests, larger organizations will have more capacity to deal with the high resources that collaboration requires (for example, high transaction costs) (Graddy and Chen 2006; Krueathep, Riccucci, and Suwanmala 2010). In this case, we also developed the analysis further by using dummy variables to discern if certain categories of the size variable had stronger effects on collaboration. The results show that the main effect is attributable to organizations that are very small, with less than 20 workers. These organizations tend to collaborate very little, whereas collaboration levels are fairly uniform for organizations that are larger than this, whatever their size. Finally, consistent with previous studies in the non-profit sector (Goldman and Kahnweiler 2000), we find that success in past collaboration is strongly correlated with engaging in current collaborations. This is because successful collaboration in the past enhances trust between partners (Gulati 1995; Gulati and Sytch 2008), and as a result, managers are more willing to consider collaborating again.

Insert Table 4 about Here

We also assessed if the impact of chief executives is even stronger in certain circumstances. More specifically, we included interaction terms to assess whether the management effects are stronger in complex environments and small organizations. The attributes of chief executives that are associated with more collaboration (youth, 
education and self-development) may be even more important when the environment is complex and difficult to manage. Collaboration has been identified as a strategic solution to respond to complex problems (Bryson, Crosby and Stone 2006). Similarly, the attributes of chief executives may have greater force in small organizations where straightforward and direct communication to staff of a pro-collaboration stance is possible. As table 5 shows, the effects of education and a concern for self-development are stronger when environmental complexity is high. By contrast, we did not find statistical support for the idea that chief executive effects on collaboration are stronger in small organizations. Thus, at least in this data set, the link between chief executive characteristics and collaboration is moderated by environmental complexity rather than organizational size. However, it is possible that our results are constrained by our sample, and that the size moderator may emerge as significant in a larger sample.

\section{Insert Table 5 about Here}

Lastly, in this study we are assessing collaboration in organizations from several fields. As noted earlier in the paper, previous research has found significant differences between the field of activity of the organizations being studied and their collaboration levels (Agranoff and McGuire 2003; Krueathep, Riccucci, and Suwanmala 2010). To test this in our sample, we ran the Kruskal Wallis test between the fields of activities and we also assessed the studentized residuals of the OLS. The Kruskal Wallis test results show no statistically significant differences in the collaboration of public organizations across sectors $\left(\chi^{2}=8.382\right.$, with a sig. $\left.=.755\right)$. Figure 1 illustrates the scatter plot of the distribution of the studentized residuals for each field of activity. This supports the findings of the Kruskal Wallis test, indicating no significant differences in collaboration across each field of activity. 
Overall, the results of this study support upper echelons theory by showing that, after controlling for several environmental and organizational variables, the top manager's personal characteristics influence the decisions of public organizations to develop activities via collaboration. In the next section, the theoretical and managerial implications of these findings are discussed, as well as the limitations of our study.

\section{CONCLUSION}

The collaborative public manager has specific characteristics that have been the central topic of several studies (Fleishman 2009; McGuire 2002, 2006; Williams 2002). However, these characteristics have not previously been considered when developing models to understand why public organizations engage in inter-organizational collaborations. Using upper echelons theory (Hambrick and Mason 1984), we provide empirical evidence that the personal attributes of top managers influence interorganizational collaboration. By analyzing data from a large sample of Catalan public managers, our results show that the personal characteristics of chief executives (their age, education, and orientation towards self-development) are strongly correlated with collaboration by public organizations. Our results are a starting point for considering how the characteristics of public managers influence several aspects of collaboration, such as its development or its performance. This represents a research opportunity to focus on the characteristics of senior managers when understanding the strategic actions of public organizations.

Of course, our evidence is limited in several ways that must be considered. The results of this study are very much contingent on how collaboration was measured. We addressed collaboration by assessing a subset of major organizational activities that 
public organizations can develop with others. However, the collaborative process is a very intricate concept that may encompass other perspectives that have not been considered in the present article. Another important extension of this line of work is to include the significance that these collaborations have for each organization. In this vein, future research should measure not only the number of collaborations but also their intensity. In addition, we do not consider the motives that each organization may have to develop collaborations. How these motives mediate the relationship between the chief executive characteristics and the degree of organizational collaboration is an important research question that should be addressed in future studies. It would also be of how different governance mechanisms influence the likelihood of developing collaborations.

Furthermore, substantial work remains to be done to refine the conceptualization and measurement of the characteristics of chief executives in the public sector. For example, we considered the title of the manager's degree to evaluate if the manager had been educated in a business related field. This measure covered most of the businessrelated education that managers receive, but it should be noted that some universities have a broad range of courses and in some cases these can be aimed at providing managerial skills to those students from non-business related fields. Hence, future research should consider any specific business management education that the manager has received. Future studies could also include the effect of other personal characteristics (such as managers' risk-taking orientation, their degree of public service motivation, or their bureaucratic personality) to evaluate whether these core public management variables also influence the degree of collaboration in public organizations. 
Regarding the generalizability of our results, it should be noted that our entire sample was formed by executive agencies. These agencies have been acknowledged to be more collaborative than central government departments (McGuire and Silvia 2010; Smith 2009), perhaps because of their quasi-independence. Thus, future studies should test whether senior managers have the same influence on collaboration in other types of public organizations.

In conclusion, our findings contribute to two growing streams of research: the impact of chief executives on organizational strategy in the public sector, and the determinants of collaboration. This paper is a first step towards recognition of the impact of top managers on inter-organizational collaboration. This comes at a time where collaboration has become a fundamental activity for most, if not all, public organizations (Krueathep, Riccucci, and Suwanmala 2010). The evidence in this paper suggests that collaboration is partly dependent on the characteristics of senior managers, and that organizations seeking to expand their collaborative activities are more likely to achieve this if they are led by managers who are younger, highly educated and keen to develop their managerial skills. More broadly, our evidence suggests that chief executives make a difference to organizational strategy, and that upper echelons theory may be relevant to answering a range of public management research questions.

\section{REFERENCES}

Agranoff, Robert. 2006. Inside collaborative networks: Ten lessons for public managers. Public Administration Review 66:56-65.

Agranoff, Robert, and Michael McGuire. 2003. Collaborative public management: New strategies for local governments. Washington, D.C.: Georgetown University Press. 
Aldrich, Howard. 1989. Networking among women entrepreneurs. In Women-owned businesses, ed. O. Hagen, C. Rivchun, and D. Sexton, 103-132. New York, NY: Praeger.

Alter, Catherine., and Jerald Hage. 1993. Organizations working together. Newbury Park, CA: Sage Publications, Inc.

Ansell, Chris, and Alison Gash. 2008. Collaborative governance in theory and practice. Journal of Public Administration Research and Theory 18:543-571.

Avellaneda, Claudia N. 2009. Municipal performance: Does mayoral quality matter? Journal of Public Administration Research and Theory 19:285-312.

Bamber, Linda S., John Jiang, and Isabel Y. Wang. 2010. What's my style? The influence of top managers on voluntary corporate financial disclosure. The Accounting Review 85:1131-1162.

Bantel, Karen A., and Susan E. Jackson. 1989. Top management and innovations in banking: Does the composition of the top team make a difference? Strategic Management Journal 10:107-124.

Bardach, Eugene. 1998. Getting agencies to work together. The practice and theory of managerial craftmanship. Washington, D.C.: Brookings Institution Press.

Barker, Vincent L., and George C. Mueller. 2002. CEO characteristics and firm R\&D spending. Management Science 48:782-801.

Blanc-Brude, Frédéric, Hugh Goldsmith, and Timo Välilä. 2007. Public-private partnerships in Europe: An update. Luxembourg: European Investment Bank.

Brudney, Jeffrey L., Sergio Fernandez, Jay E. Ryu, and Deil S. Wright. 2005. Exploring and explaining contracting out: Patterns among the american states. Journal of Public Administration Research and Theory 15:393-419. 
Brush, Candida G. 1992. Research on women business owners: Past trends, a new perspective and future directions. Entrepreneurship: Theory and Practice 16:530.

Bryson, John M., Barbara C. Crosby, and Melissa M. Stone. 2006. The design and implementation of cross-sector collaborations: Propositions from the literature. Public Administration Review 66:44-55.

Buttner, Holly E. 2001. Examining female entrepreneurs' management style: An application of a relational frame. Journal of Business Ethics 29:253-269.

Carlsson, Gosta, and Katarina Karlsson. 1970. Age, cohorts and the generation of generations. American Sociological Review 35:710-718.

Carpenter, M. A., W. G. Sanders, and H. B. Gregersen. 2001. Bundling human capital with organizational context: The impact of international assignment experience on multinational firm performance and CEO pay. Academy of Management Journal 44:493-511.

Chaganti, Rajeswararao, and Rakesh Sambharya. 1987. Strategic orientation and characteristics of upper management. Strategic Management Journal 8:393-401.

Chatterjee, Arijit, and Donald C. Hambrick. 2007. It is all about me: Narcissistic chief executive officers and their effects on company strategy and performance. Administrative Science Quarterly 3:351-386.

Child, John. 1974. Managerial and organizational factors associated with company performance. Journal of Management Studies 11:13-27.

Chown, Sheila M. 1960. The wesley rigidity inventory: A factor-analytic approach. Journal of Abnormal and Social Psychology 61:491-494.

Cyert, Richard M., and James G. March. 1963. A behavioral theory of the firm. Endlewood Cliffs, NJ.: Prentice Hall. 
Damanpour, Fariborz, and Marguerite Schneider. 2009. Characteristics of innovation and innovation adoption in public organizations: Assessing the role of managers. Journal of Public Administration Research and Theory 19:495-522.

Eisenhardt, Kathleen M., and Claudia B. Schoonhoven. 1996. Resource-based view of strategic alliance formation: Strategic and social effects in entrepreneurial firms. Organization Science 7:136-150.

Fox, Richard L., and Robert A. Schuhmann. 1999. Gender and local government: A comparison of women and men city managers. Public Administration Review $59: 231-242$.

Galbraith, Jayr R. 1974. Organization design: An information processing view. Interfaces 4:28-36.

Giacalone, Robert A., and Kenneth R. Thompson. 2006. Business ethics and social responsibility education: Shifting the worldview. Academy of Management Learning and Education 5:266-277.

Goerdel, Holly T. 2006. Taking initiative: Proactive management and organizational performance in networked environments. Journal of Public Administration Research and Theory 16:351-367.

Goldman, Samuel, and William M. Kahnweiler. 2000. A collaborator profile for executives of nonprofit organizations. Nonprofit Management and Leadership $10: 435-450$.

Graddy, Elizabeth A., and Bin Chen. 2006. Influences on the size and scope of networks for social service delivery. Journal of Public Administration Research and Theory 16:533-552.

Grimm, Curtis M., and Ken G. Smith. 1991. Management and organizational change: A note on the railroad industry. Strategic Management Journal 12:557-562. 
Gulati, Ranjay. 1995. Does familiarity breed trust? The implications of repeated ties for contractual choice in alliances. Academy of Management Journal 38:85-112.

Gulati, Ranjay, and Maxim Sytch. 2008. Does familiarity breed trust? Revisiting the antecedents of trust. Managerial and Decision Economics 29:165-190.

Guy, Mary E., and Meredith A. Newman. 2004. Women's jobs, men's jobs: Sex segregation and emotional labor. Public Administration Review 64:289-298.

Hair, Joseph F., Rolph E. Anderson, Ronald L. Tatham, and William C. Black. 2006. Multivariate data analysis. Upper Saddle River, N.J. : Prentice Hall.

Hambrick, Donald C. 2007. Upper echelons theory: An update. Academy of Management Review 32:334-343.

Hambrick, Donald C., Marta A. Geletkanycz, and James W. Fredrickson. 1993. Top executive commitment to the status quo: some tests of its determinants. Strategic Management Journal 14: 401-418.

Hambrick, Donald C., and Gregory D. S. Fukutomi. 1991. The seasons of a CEO`s tenure. Academy of Management Review 16:719-742.

Hambrick, Donald C., and Phyllis A. Mason. 1984. Upper echelons: The organization as a reflection of its top managers. Academy of Management Review 9:193-206.

Hart, Peter, and John Mellors. 1993. Management youth and company growth: A correlation? Management Decision 4:50-53.

Hodge, Graeme A., and Carsten Greve. 2007. Public-private partnerships: An international performance review. Public Administration Review 67:545-558.

Jacobson, Willow S., Christine K. Palus, and Cynthia J. Bowling. 2010. A woman's touch? Gendered management and performance in state administration. Journal of Public Administration Research and Theory 20:477-504. 
James, Oliver. 2003. The executive agency revolution in Whitehall: Public interest versus bureau-shaping perspectives. Basingstoke, UK: Palgrave Macmillan.

Jensen, Michael, and Edward J. Zajac. 2004. Corporate elites and corporate strategy: How demographic preferences and structural position shape the scope of the firm. Strategic Management Journal 25:507-524.

Kickert, Walter, Erik-Hans Klijn, and Joop F. M. Koppenjan. (Eds.). 1997. Managing complex networks: Strategies for the public sector. London. UK: Sage Publications.

Koontz, Tomas M., and Craig W. Thomas. 2006. What do we know and need to know about the environmental outcomes of collaborative management? Public Administration Review 66 (s1): 111-21.

Koppenjan, Joop F. M., and B. Enserink. 2009. Public-private partnerships in urban infrastructures: Reconciling private sector participation and sustainability. Public Administration Review 69:284-296.

Krueathep, Weerasak, Norma M. Riccucci, and Charas Suwanmala. 2010. Why do agencies work together? The determinants of network formation at the subnational level of government in Thailand. Jounral of Public Administration Research and Theory 20:157-185.

Longo, Francisco. 2008. La direcció pública professional a les administracions públiques de Catalunya: Estudi sobre les condicions actuals i els reptes per a la seva institucionalització $i$ el desenvolupament. Barcelona, CA: Diputació de Barcelona.

Lundin, Martin. 2007. Explaining cooperation: How resource interdependence, goal congruence, and trust affect joint actions in policy implementation. Journal of Public Administration Research and Theory 17:651-672. 
Mandell, Myrna P., and Toddi A. Steelman. 2003. Understanding what can be accomplished through interorganizational innovations. Public Management Review 5:197-224.

March, James G., and Herbert Simon. 1958. Organizations. New York: Wiley.

Martínez-Alonso, Jose L., and Tamyko Ysa. 2003. Las personificaciones instrumentales locales en Cataluña. Organismos autónomos, consorcios, mancomunidades y sociedades públicas. Madrid: Ministerio de Administraciones Públicas.

McGuire, Michael. 2006. Collaborative public management: Assessing what we know and how we know it. Public Administration Review 66:33-43.

McGuire, Michael. 2009. The new professionalism and collaborative activity in local emergency management. In The collaborative public manager, ed. R. O'Leary and L. B. Bingham, 71-93. Washington, D.C.: Georgetown University Press.

McGuire, Michael, and Chris Silvia. 2009a. Does leadership in networks matter? Examining the effect of leadership behaviors on managers' perceptions of network effectiveness. Public Performance and Management Review 33:34-62.

McGuire, Michael, and Chris Silvia. 2009b. How good? The impact of leadership on network effectiveness. Paper presented at the 10th Public Management Research Association Conference, October 1-3. Columbus, $\mathrm{OH}$.

McGuire, Michael, and Chris Silvia. 2010. The effect of problem severity, managerial and organizational capacity, and agency structure on intergovernmental collaboration: Evidence from local emergency management. Public Administration Review 70: 279-288.

Meier, Kenneth J., Laurence J. O'Toole Jr., and Holly T. Goerdel. 2006. Management activity and program performance: Gender as management capital. Public Administration Review 66:24-36. 
Miller, Danny. 1991. Stale in the saddle: CEO tenure and the match between organization and environment. Management Science 37:34-52.

Miller, Karen. 2009. Gendered nature of managerialism? Case of the national health service. International Journal of Public Sector Management 22:104-113.

Mills, Albert J. 1988. Organization, gender and culture. Organization Studies 9:351369.

Mitchell, Victoria L., and Barrie R. Nault. 2007. Cooperative planning, uncertainty, and managerial control in concurrent design. Management Science 53:375-389.

Mullin, Megan, and Dorothy M. Daley. 2010. Working with the state: Exploring interagency collaboration within a federalist system. Journal of Public Administration Research and Theory 20:757-778.

Nadkarni, Sucheta, and Pol Herrmann. 2010. CEO personality, strategic flexibility, and firm performance: The case of the Indian business process outsourcing industry. Academy of Management Journal 53:1050-1073.

Noordegraaf, Mirko, Pauline Meurs, and Annemiek Montijn-Stoopendaal. 2005. Pushed organizational pulls. Public Management Review 7:25-43.

O'Leary, Rosemary, and Lisa B. Bingham. 2009. The collaborative public manager. Washington, D.C.: Georgetown University Press.

O'Toole Jr., Laurence J. 1997. Treating networks seriously: Practical and research-based agendas in public administration. Public Administration Review 57:45-52.

Podsakoff, Philip M., Scott B. MacKenzie, Jeong-Yeon Lee, and Nathan P. Podsakoff. 2003. Common method biases in behavioral research: A critical review of the literature and recommended remedies. Journal of Applied Psychology 88:879903. 
Podsakoff, Philip M., and Dennis W. Organ. 1986. Self-reports in organizational research: Problems and prospects. Journal of Management 12:531-544.

Rainey, Hal G. 2003. Understanding and managing public organizations (3rd ed.). San Francisco, CA: Jossey-Bass.

Rethemeyer, Karl R. 2005. Conceptualizing and measuring collaborative networks. Public Administration Review 65:117-121.

Silvia, Chris, and Michael McGuire. 2010. Leading public sector networks: An empirical examination of integrative leadership behaviors. Leadership Quarterly 21: $264-277$.

Simon, Herbert A. 1947. Administrative behavior. New York: Macmillan.

Simon, Herbert A. 1982. Models of bounded rationality. Cambridge, MA: MIT Press.

Smith, Craig R. 2009. Institutional determinants of collaboration: An empirical study of county open-space protection. Journal of Public Administration Research and Theory 19:1-21.

Sorenson, Ritch L., Cathleen A. Folker, and Keith H. Brigham. 2008. The collaborative network orientation: Achieving business success through collaborative relationships. Entrepreneurship: Theory and Practice 32:615-634.

Steijn, Bram, Erik-Hans Klijn, and Julian Edelenbos. 2011. Public private partnership: Added value by organizational form or management? Public Administration 89.

Stevens, John M., Janice M. Beyer, and Harrison M. Tryce. 1978. Assessing personal, role and organizational predictors of managerial commitment. Academy of Management Journal 21:380-396.

Thomson, James D. 1967. Organizations in action. New York, NY: McGraw-Hill.

Thomson, Ann Marie, and James L. Perry. 2006. Collaboration processes: Inside the black box. Public Administration Review 66:20-32. 
Wajcman, Judy. 1998. Managing like a man: Women and men in corporate management. University Park, PA: The Pennsylvania State University Press.

Weiss, Janet A. 1987. Pathways to cooperation among public agencies. Journal of Policy Analysis and Management 7:94-117.

Williams, Paul. 2002. The competent boundary spanner. Public Administration 80:103124. 


\section{TABLES AND FIGURES}

Table 1 Frequencies for Fields of Activity Analyzed

\begin{tabular}{|c|c|c|c|}
\hline Field of Activity & Cases $(\%)$ & Field of Activity & Cases $(\%)$ \\
\hline Education Promotion & 10.6 & Transport and Infrastructures & 11.9 \\
\hline Health Care & 17.2 & Tourism Promotion & 7.0 \\
\hline House and Urbanism & 6.2 & Sports and Physical Activities & 4.8 \\
\hline Water Provision & 2.2 & Culture Promotion and Diffusion & 15.9 \\
\hline Waste Disposal & 5.7 & Economy Promotion & .9 \\
\hline Environmental Programs & 4.0 & Others & 7.0 \\
\hline $\begin{array}{l}\text { Social Communication and } \\
\text { Citizens Participation }\end{array}$ & 6.6 & & \\
\hline
\end{tabular}

Table 2 Frequencies for Collaborative Activities

Frequency (\%)

\begin{tabular}{lcccccc}
\hline Collaborative Activity & 0 & $1-19$ & $20-29$ & $30-39$ & $40-49$ & +50 \\
\hline Informal Cooperation & .4 & 12.1 & 6.3 & 13.5 & 22.4 & 45.3 \\
Mutual Aid Agreements & 2.3 & 15.8 & 9.0 & 16.3 & 23.5 & 33.0 \\
Provide Training & 5.0 & 17.6 & 13.1 & 23.0 & 21.6 & 19.8 \\
Receive Training & 4.1 & 23.2 & 16.4 & 22.3 & 28.6 & 5.5 \\
Joint Planning & 1.8 & 18.9 & 17.6 & 20.3 & 23.9 & 17.6 \\
Provide Equipment & 7.3 & 22.0 & 18.8 & 27.5 & 17.9 & 6.4 \\
Receive Equipment & 7.0 & 21.1 & 20.2 & 29.1 & 19.2 & 3.3 \\
Provide Technical Assistance & 4.1 & 21.6 & 28.0 & 19.7 & 19.3 & 7.3 \\
Receive Technical Assistance & 4.6 & 24.2 & 32.4 & 18.7 & 17.4 & 2.7 \\
\end{tabular}


Table 3 Descriptive Statistics and Correlations for the Quantitative Variables

\section{Considered in the Analysis}

\begin{tabular}{|c|c|c|c|c|c|c|c|c|c|c|c|}
\hline Variable & $\mathrm{M}$ & SD & 1 & 2 & 3 & 4 & 5 & 6 & 7 & 8 & 9 \\
\hline 1 Collaboration & 26.2 & 11.7 & & & & & & & & & \\
\hline 2 Age & 45.7 & 7.5 & $-.43^{* *}$ & & & & & & & & \\
\hline 3 Education & 2.6 & .7 & $.44^{* *}$ & $-.01^{*}$ & & & & & & & \\
\hline 4 Self Develop & 2.7 & 1.1 & $.49^{* *}$ & $-.19^{* *}$ & $.43^{* *}$ & & & & & & \\
\hline 5 Tenure & 5.3 & 3.2 & $-.38^{* *}$ & $.40^{* *}$ & $-.35^{* * *}$ & $-.23^{* *}$ & & & & & \\
\hline 6 Populat Dens & 5860 & 6584 & $.22^{* *}$ & .08 & $.28^{* *}$ & $.23^{* *}$ & $-.16^{*}$ & & & & \\
\hline 7 Agricult Econ & .01 & .03 & -.05 & $-.22^{* *}$ & $-.28^{* * *}$ & $-.23^{* *}$ & -.04 & $-.32^{* *}$ & & & \\
\hline 8 Size & 3.4 & 1.2 & $.19^{* *}$ & $.19^{* *}$ & $.26^{* *}$ & $.24^{* *}$ & -.08 & $.41^{* *}$ & $-.41^{* *}$ & & \\
\hline 9 Environ Com & 2.9 & 1.0 & $.35^{* *}$ & $-.31^{* *}$ & $.40^{* *}$ & $.33^{* *}$ & $-.39^{* *}$ & $.21^{* *}$ & $-.15^{*}$ & .10 & \\
\hline 10 Success Past & 3.8 & .5 & $.39^{* *}$ & -.09 & $.30^{* *}$ & $.25^{* *}$ & $-.15^{*}$ & .06 & -.06 & .06 & $.13^{*}$ \\
\hline
\end{tabular}


Table 4 Regression Results for Extent of Collaboration

\begin{tabular}{|c|c|c|c|c|c|c|c|c|c|}
\hline & \multicolumn{3}{|c|}{ Model 1} & \multicolumn{3}{|c|}{ Model 2} & \multicolumn{3}{|c|}{ Model 3} \\
\hline & Coeff. & $\mathrm{SE}$ & T-Stat & Coeff. & $\mathrm{SE}$ & T-Stat & Coeff. & $\mathrm{SE}$ & T-Stat \\
\hline Population Density & .000 & .000 & 0.594 & .000 & .000 & 1.344 & .000 & .000 & .984 \\
\hline Province Capital & 2.615 & 2.108 & 1.241 & .720 & 1.890 & .381 & 1.100 & 1.683 & .654 \\
\hline Rural Area & 5.078 & 4.218 & 1.204 & 5.082 & 3.702 & 1.373 & 3.598 & .065 & 1.100 \\
\hline Log Agricultural Economy & -.217 & .753 & -.288 & .469 & 677 & .693 & .118 & .611 & .194 \\
\hline Environmental Complexity & 3.124 & .783 & $-3.991^{* * * *}$ & 2.057 & .719 & $2.860^{* *}$ & -.571 & .727 & -.785 \\
\hline Size & & & & .851 & .610 & 1.396 & 1.071 & .553 & $1.937^{*}$ \\
\hline Standard Coll. Procedures & & & & 6.102 & 1.748 & $3.491^{* * *}$ & 4.319 & 1.588 & $2.720^{* *}$ \\
\hline Success Past Collaborations & & & & 7.135 & 1.171 & $6.095^{* * *}$ & 5.153 & 1.069 & $4.921^{* * * *}$ \\
\hline Age & & & & & & & -.519 & .095 & $-5.437^{* * *}$ \\
\hline Log Tenure & & & & & & & -.934 & 1.275 & -.732 \\
\hline Education & & & & & & & 1.750 & .977 & $1.792^{*}$ \\
\hline Functional Track & & & & & & & 2.046 & 1.342 & 1.525 \\
\hline Self-Development & & & & & & & 2.120 & .594 & $3.569^{* * *}$ \\
\hline Gender & & & & & & & .807 & 1.417 & .570 \\
\hline Constant & 14.754 & 4.325 & $3.409^{* * *}$ & -13.052 & 5.759 & $-2.267^{* *}$ & 14.622 & 6.851 & $2.134^{* *}$ \\
\hline$F$-stat & 6.065 & & & 12.672 & & & 14.141 & & \\
\hline Adjusted $R^{2}$ & .111 & & & .316 & & & .477 & & \\
\hline$\Delta R^{2}$ & $.113^{* * *}$ & & & $.210^{* * *}$ & & & $.170^{* * * *}$ & & \\
\hline
\end{tabular}


Table 5 Regression Results for Interaction Effects

\begin{tabular}{|c|c|c|c|c|c|c|}
\hline & Coeff. Model 1 & Coeff. Model 2 & Coeff. Model 3 & Coeff. Model 4 & Coeff. Model 5 & Coeff. Model 6 \\
\hline Population Density & .000 & $8,645 \mathrm{e}-005$ & .000 & .000 & .000 & .000 \\
\hline Province Capital & 1.090 & 1.324 & 1.461 & .708 & 1.085 & 1.081 \\
\hline Rural Area & 3.581 & 3.733 & $5.776^{*}$ & 4.040 & 3.725 & 3.465 \\
\hline Log Agricultural Economy & .118 & -.132 & -.113 & .199 & .073 & .160 \\
\hline Environmental Complexity & -.854 & $-4.995^{* *}$ & -5.347 & -.485 & -.576 & -.411 \\
\hline Size & $1.066^{*}$ & $.973^{*}$ & .571 & 5.246 & -.462 & 2.215 \\
\hline Standard Coll. Procedures & $4.315^{* *}$ & $4.563^{* *}$ & 4.636 & 4.370 & $4.298^{* *}$ & $4.196^{* *}$ \\
\hline Success Past Collaborations & $5.158^{* * *}$ & $5.164^{* * *}$ & 4.584 & $5.296^{* * *}$ & $5.248^{* * *}$ & $5.201^{* * *}$ \\
\hline Age & $-.536^{* *}$ & $-.498^{* * *}$ & -.484 & -.208 & $-.525^{* * *}$ & $-.515^{* * *}$ \\
\hline Log Tenure & -.947 & -1.025 & -1.207 & -1.088 & -.837 & -.911 \\
\hline Education & $1.759^{*}$ & -3.271 & 1.635 & $1.830^{*}$ & -.194 & $1.722^{*}$ \\
\hline Functional Track & 2.049 & 1.998 & 2.083 & 1.901 & 2.071 & 2.141 \\
\hline Self-Development & $2.121^{* * *}$ & $2.014^{* * *}$ & -3.387 & $2.003^{* * *}$ & $2.097^{* * *}$ & $3.579^{* *}$ \\
\hline Gender & .808 & .768 & .734 & .759 & .692 & .832 \\
\hline Age x Env. Complex. & .006 & & & & & \\
\hline Education x Env. Complex. & & $1.728^{*}$ & & & & \\
\hline Self-Development x Env. Complex. & & & $1.839^{* * *}$ & & & \\
\hline Age x Size & & & & -.088 & & \\
\hline Education x Size & & & & & .562 & \\
\hline Self-Development x Size & & & & & & -.412 \\
\hline Constant & 15.445 & $25.568^{* *}$ & $29.763^{* * *}$ & .124 & $19.588^{* *}$ & 10.166 \\
\hline$F$-stat & $13.129^{* * *}$ & $13.606^{* * *}$ & $14.854^{* * *}$ & $13.427^{* * *}$ & $13.230^{* * *}$ & $13.274^{* * *}$ \\
\hline Adjusted $R^{2}$ & .474 & .484 & .507 & .480 & .476 & .477 \\
\hline$\Delta R^{2}$ & .000 & $.009^{*}$ & $.031^{* * *}$ & .006 & .002 & .003 \\
\hline
\end{tabular}


Figure 1 Collaboration in each Field of Activity

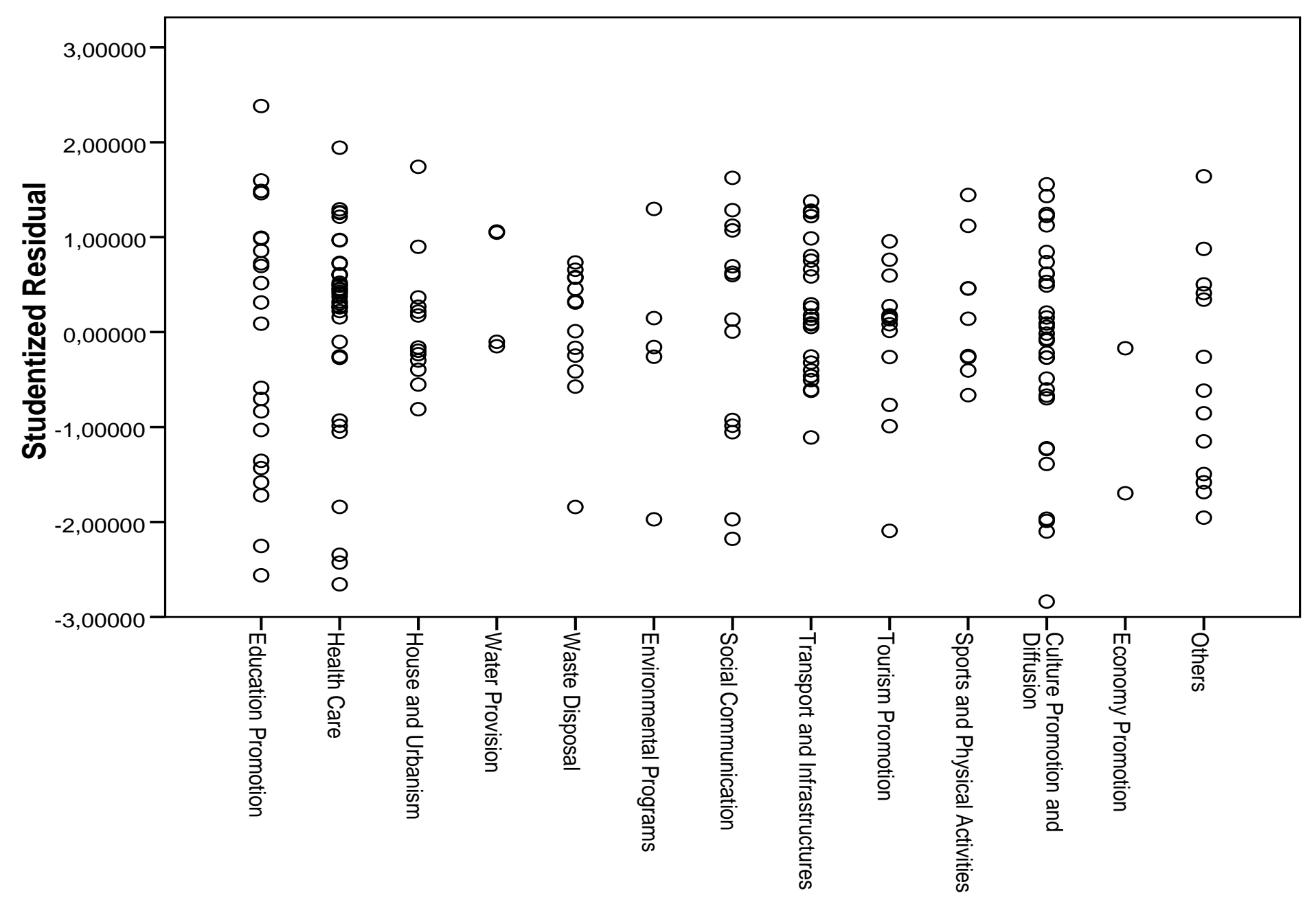

Field_of_Activity 